\title{
ANIMATION WITH CONCURRENT NARRATION VERSUS NARRATION IN PHYSICAL EDUCATION LESSON
}

\author{
Panagiotis Ioannou ${ }^{1}$, Panteleimon Bakirtzoglou ${ }^{2}$ \\ ${ }^{1}$ University of Patras, Depatment of Primary Education, Patras, Greece \\ ${ }^{2}$ Aristotle University of Thessaloniki, School of Physical Education and Sports Science, Thessaloniki, Greece
}

\begin{abstract}
The purpose of the present study was to compare the effects of two different teaching methods on students' comprehension during Physical Education lesson: narration versus animation with concurrent narration, during teaching shot put event. Thirty primary school children (boys and girls) volunteered to participate in this study. In experiment students listened (narration) and viewed (animation with narration) the presentation of two shot putting styles. A problem-solving and a retention test were used to evaluate students' comprehension. Results showed that students' comprehension was better when shot putting styles were presented through a mixed model (animation and narration group) than a single (narration). The animation with concurrent narration group performed better than the narration group, in problem-solving $(\mathrm{M}=4.91, \mathrm{SD}=1.36)$ and in retention test $(\mathrm{M}=5.98, \mathrm{SD}=1.28) \mathrm{t}(28)=1.89 \mathrm{p}<0.01$. An instructional implication is that pictures with words is more effective way of teaching when they occur continuingly in time, than only words during Physical Education lesson.
\end{abstract}

Key words: DUAL CODE THEORY / PICTURES / WORDS / THROWING EVENT

\section{INTRODUCTION}

New technologies, educational software programs and Multimedia learning environments are based and apply the principle of Multimodality as a teaching method (Crafton, Brennan, \& Silvers, 2007). Multimodality actually refers to a system of learning with multiple didactic teaching tools: visual like letters, graphs and pictures (static or animated), audile like voices and sounds and kinetic like hand making or hand solving (Cope, \& Kalantzis, 2009).

According to Mayer and Moreno (2003), in a Multimedia learning environment information is presented in two or more perceptual modalities, visual (pictures, images, graphs) and auditory (sounds, words). Through technology information and knowledge is presented in multiple modalities using computer-based dynamic media such as animations and audio (Kay, 2012; Narayanan, \& He- garty, 2002). Multimedia learning occurs when students build mental presentations from words and pictures that are presented to them. Students learn more deeply from a combination of words and pictures than from words alone, known as the multimedia effect (Mayer, 2003).

A cognitive theory of Multimedia learning known as Dual-coding theory, advanced by Paivio (1986) is based on main assumption that there are two separates channels (auditory and visual) processing information. In agreement with this theory, words and pictures activate independent visual and verbal codes. According to Dual-code theory, narration (verbal) is proceeded in the auditory-verbal channel. In some lessons, like History, Language, Geography and Religion, narration is the most common and effective style or method of teaching aiming to motivate children constructing knowledge (Bell, 2002; Zipes, 2013). However the effect of narration on students' learning performance is 
controversial. There is empirical evidence that narration does not have positive effects on students' learning performance. Results showed that when students listen to or read only explanations that are presented to them as words are unable to remember most of the key ideas (Mayer, 1997; 1999a; 1999b).

Animation (visual) according to Dual-code theory is proceeded in the visual channel. One of the main reasons of the growing popularity of animated graphics seems to be the belief that animation is more interesting, aesthetically appealing and therefore more motivating when uses pedagogical agent (Kim, Yoon, Whang, Tversky, \& Morrison, 2007; Young, \& Pass, 2015). For some authors, children prefer animation due to its attractiveness (Perez, \& White, 1985; Sirikasem, \& Shebilske, 1991). However the effect of animation in students' comprehension is controversial (Betrancourt, 2005; Kim et al., 2007). Some studies showed significant and actual effects and improvement on students learning by animated graphics, on the other side some studies showed opposite results and detrimental to learning performance. Some basic problems of the experiments between static and animated graphs, is that studies that comparing animation have not equivalent procedures (Betrancourt, 2005; Mayer, Hegarty, Mayer, \& Cambell, 2005).

The comparison between animation (pictures) and narration (words) has been investigated by many authors in a variety of lesson as Physics, Mathematics, Geometry, Biology, Astronomy and Mechanics (Kieras, 1992; Hegarty, Kriz, \& Gate, 2003; Rebetez , Sangin, Betrancourt, \& Dillenbourg, 2004; Rieber, 1990). Furthermore, the comparison between animation with concurrent narration (pictures with words) and narration (words) showed that a mixed information model (animation with narration) is more effective, than a single (narration only) information model (Mayer, 1989; Mayer, \& Gallini, 1990; Mayer, \& Anderson, 1992; Moreno, \& Mayer, 1999). Students learn better when words and pictures are presented concurrently in time, rather than words only or pictures only are used as teaching methods (Moreno, \& Mayer, 1999).

Physical Education lesson uses a variety of teaching styles renamed from Mosston and Ashworth's work (Metzler, 2011). Methods of teaching may include lecture method (words or narra- tion) and also observation or visualization method (models, video, computer-assisted instruction and animation). Narration during Physical Education lesson is often used in all ages and at any level of physical performance, for teaching new skills and also as a method of giving instructions. The use of animation during physical education lesson is performed by the method of display or by using a model-template to learn, improve or correct new skills. However, narration and animation methods of teaching through multimedia are both used in primary, secondary, high school and college to enhance students' motivation and also cognitive and physical performance through facilitation of active and experiential learning (Fiorentino, \& Castelli, 2005; Goran, \& Reynolds, 2005). Computer technology and multimedia instructional environments have become an integral part of Physical Education (Siskos, Antoniou, Papaioannou, \& Laparidis, 2005). The effect of pictures with words (animation with narration) versus words only (narration) on students' performance during Physical Education lesson is missing form the present literature.

Therefore the purpose of the present study is to compare the effectiveness of animation with concurrent narration (pictures with words) and narration (words only) on students' performance during teaching Physical Education lesson.

\section{METHOD}

\section{Participants}

Thirty $(\mathrm{n}=30)$ school children in the $5^{\text {th }}$ and $6^{\text {th }}$ grade from 4 primary public schools from the prefecture of Thessaloniki (Greece), were recruited for the purposes of this study with the design of random sampling. Children reported low levels of prior experience viewing and performing shot put event, due to the lack of teaching shot put event (Glide and Spin putting style) in the curriculum of Physical Education lesson during the current and previous years. Half of the subjects served in the Narration Group (words only) and half of the subjects served in the Animation with concurrent 
Narration Group (pictures with words). Groups were designed by the method of random selection.

\section{Materials and Apparatus}

The paper-and-pencil material consisted of a subject questionnaire, one test sheet containing questions and possible explanations-answers (problem-solving test) and a retention test. The questionnaire asked students to indicate their age and gender. It also contained a shot put event knowledge scale in which students were asked to rate on a 5 -point scale ( $1=$ very little, $3=$ average, $5=$ very much) their level of knowledge of shot put event and to place check marks next to each of five shot put event-related items that presented to them (e.g., "I know the skills of throwing at the track and field sport", "I have thrown a heavy spherical object", "I know the putting styles", "I know when a shot is or not valid", "I know the phases of shot putting styles").

The problem-solving test contained the six (6) following questions: "What is the difference between the Glide and Spin putting style?", "What is the technique of Glide putting style during preparation phase?", "What is the technique of Glide shot putting style during release phase?", "What is the technique of Spin putting style during preparation phase?", "What is the technique of Spin putting style during power position?", "What will happen if during the throwing motion the athlete touches the top of the iron ring or throws on or outside of the foul lines?". The retention test sheet contained the following printed instruction: "Please write down a description of Glide and Spin putting style".

The computer-based material consisted of two video animations of the shot put event (Glide and Spin shot put technique), lasting approximately 2 min each. Multimedia programs constructed using Adobe Reader 12 Version (for Windows). The first animation portrayed a monochrome figure of an athlete during Glide shot put technique and it was intended to depict the basic phases of this putting style and some basic rules of the sport along with concurrent narration that was broken into $12 \mathrm{seg}$ ments (Figure 1). The second animation portrayed a monochrome figure of an athlete during Spin shot put technique, and it was intended to depict the basic phases of this putting style and some basic rules of the sport along with concurrent narration that was broken into 11 segments (Figure 2). Narration material consisted of an approximately 325word description about Glide shot put technique, and it was intended to depict its basic phases and rules and 319-word description about Spin shot put technique, and it was intended to depict its basic phases and rules (Walmsley, 2004). Narration was presented in digitized speech spoken in a male voice lasting approximately 2 min each. During the narration all children received brief instructions keeping quiet and been concentrated on researcher's voice.

Selected animation frames and corresponding narration of Glide shot put technique follows.

Glide shot put technique. Preparation phase: place shot against neck and under the jaw with right hand, left hand support leg in tall position, bend over $45-90^{\circ}$, back facing the direction of throwing, body weight in one leg, body in T-shape, swinging leg from outstretched position behind support leg (Figure 1).

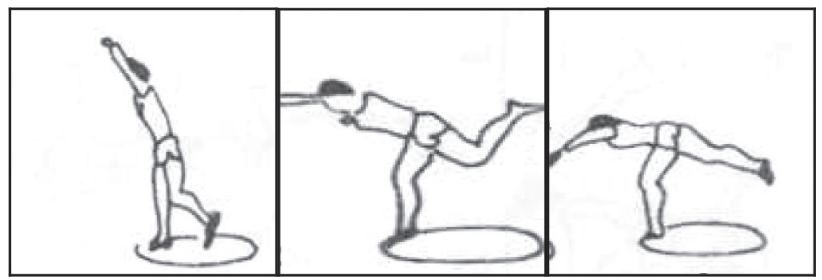

Figure 1. Preparation phase

Glide Phase: support leg from a tall to a bent position, body unseats backwards, free leg is driven low towards the stopboard, support leg extends over its heel maintaining the circle, left and right feet land quickly one after the other (Figure 2). Power position: body weight is held on right foot, heel of the right foot and toe of the left foot are aligned, shoulder line behind hip line, head and left arm are facing towards the back of the circle, righ leg turn $90^{\circ}$ toward the front of circle (Figure 3).

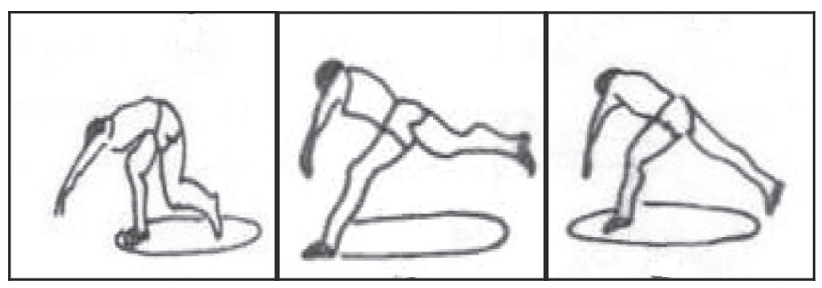

Figure 2. Glide Phase 


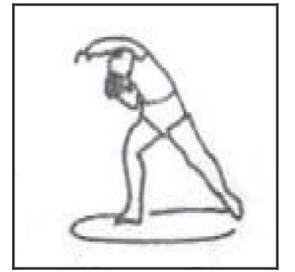

Figure 3. Power position

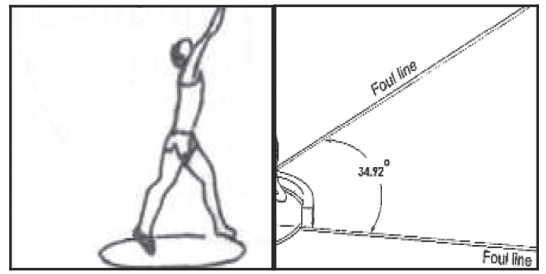

Figure 6. Recovery phase
Delivery phase: When right leg touches the middle of the circle, it immediately turns and lift, body weight is transferred from the right side to the left leg, left leg is driven hard downwards into the circle, body extends upwards, left arm and left side of trunk are braced as hard as possible, right elbow is raised and pushed forwards towards the sector, right leg turn and lift (Figure 4). Release phase: arm strike is initiated after full extension of the legs and trunk, left arm is braced and held close to trunk, throwing arm up approximately to $45^{\circ}$ angle, arm/hand is pushed out with the thumb pointing downwards, release shot forward pushing with right leg (Figure 5).

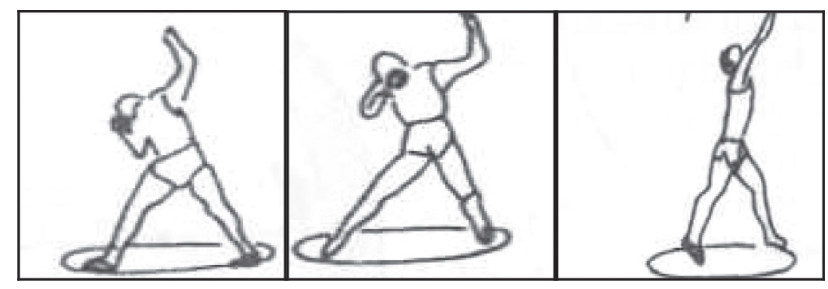

Figure 4. Delivery phase

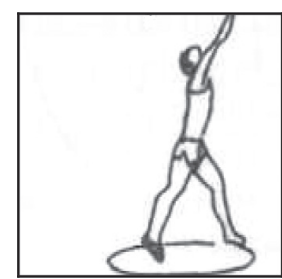

Figure 5. Release phase

Recovery phase (Figure 6): feet contact should be maintained as long as possible (explosive leg action may cause legs to come off ground at release), good follow-through is essential for balance, shot is is not valid if the athlete touches the top of the toeboard or outside the circle or if the ball falls outside of the borders to the left and to the right, but is valid if falls on the borders (foul line).
Selected animation frames and corresponding narration of Spin shot put technique follows.

Spin-Rotation shot put technique. Preparation phase: stand at the near of circle, shoulders opposite throwing direction, place shot on the base of your fingers against your neck (right-handed throwers), throwing elbow pointed outward away from body, head up, shoulders level in same position, extend your left arm to the side, rotate your upper body one quarter turn to the right, bent right knee (Figure 7). Rotation (entry $1 \& 2$ ) phase: shift weight to left side as you pivot on, turn into the circle, then turn left foot, bent left knee slightly, flattern left foot, transfer the center of gravity to left side, begin pushing off right foot, land right foot in the middle of the circle, pivot and turn left leg (Figure 2).

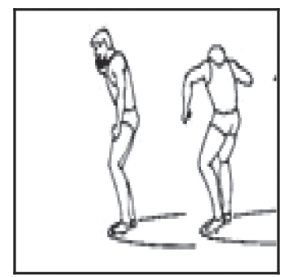

Figure 7. Preparation phase

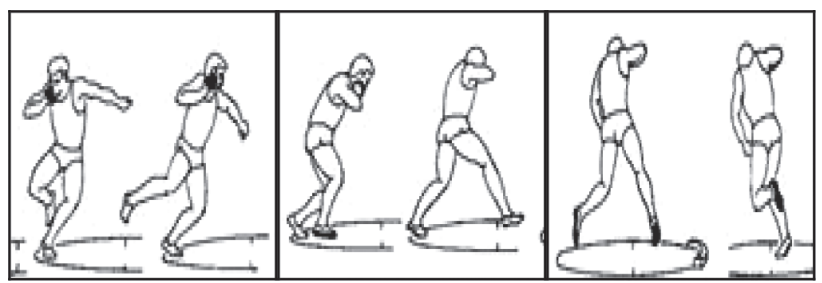

Figure 8. Rotation (entry $1 \& 2$ ) phase

Rotation (drive 1 \& 2) phase: continue sweeping right leg around until it lands in the center of circle, right elbow pointed toward the target, right knee bent, lift left knee and circle it toward the front of the ring, left arm extends toward the target lifting left shoulder (Figure 9). Power position phase: left arm pointed toward the target, left leg straight and right knee bent, right shoulder lower 
than the left and parallel with ground, weight on right foot (Figure 10).

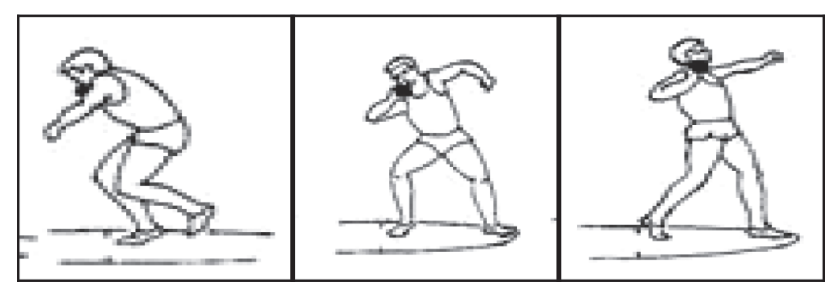

Figure 9. Rotation (drive $1 \& 2$ ) phase

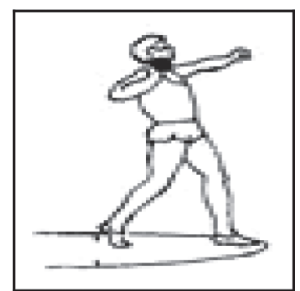

Figure 10. Power position phase

Release phase: left arm pointed toward the target, left leg straight and right knee bent, right shoulder lower than the left and parallel with ground, throwing arm up approximately to $45^{\circ}$ angle, weight on right foot, release shot forward pushing with right leg (Figure 11). Recovery phase (Figure 12): as you push with right foot lift your leg and pivot on your left, when right foot land hop on it and continue spinning, a good follow-through is essential for balance. A shot is not valid if the athlete touches the top of the toeboard or outside the circle or if the ball falls outside of the borders to the left and to the right, but is valid if falls on the borders (foul line).

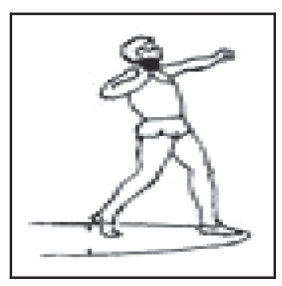

Figure 11. Release phase

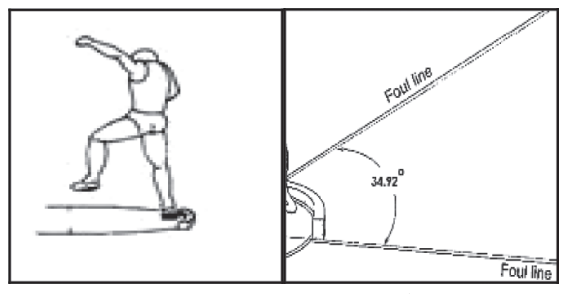

Figure 10. Recovery phase
Apparatus consisted of one Toshiba Satellite C55-B5298 laptop with 15-in., connected with a projector EPSON EH-TW570. Headphones FRISBY FS$75 \mathrm{NU}$ were plugged into the audio output of Toshiba laptop. A stopwatch was used to time the tests.

\section{Procedure}

Five days before the measures children and parents were both informed in writing and orally about the objectives and scopes of the study. An informed consent was given to child's parents. This form clearly stated that participation is voluntary and that child may be withdrawn at any time. Consent was obtained in accordance with the policies of the Ethics Committee of Aristotle University of Thessaloniki.

Measures began early in the morning (09.00am). Students were randomly assigned to treatment groups (narration group and animation with concurrent narration group). They were instructed that they would receive a brief narration (narration group) about Glide and Spin shot put event and a brief multimedia presentation (animation with concurrent narration) about Glide and Spin shot put event, that they should pay attention and after the presentation that they have to answer some questions about the material. First, students completed the subject questionnaire at their own rates. Second, after receiving brief instructions, students (narration group) listened the narration of Glide and Spin shot put event three times by the researcher and half of the other students (animation with concurrent audio narration) viewed the animation with narration of Glide and Spin shot put event three times also. Narration and Animation presentations lasted approximately 2 min each. Third, students wrote answers to problem-solving in a period of 5 minutes. Fourth, after problem-solving students began to answer to retention test. Students were given 5 minutes to write as many solutions as possible to each question. During this time, students could not return to previous question or continue to the subsequent question.

In the questionnaire students rated their knowledge on shot put event as average and indicated that they had few experiences in the field with this event. Retention test was scored by determining how many of seven key ideas were included in the program. One (1) point was given for each of the following ideas: (a) body in T-shape (Glide style), rotation (Spin style), (b) shot placed against neck-under jaw, (c) throwing 
arm up to $45^{\circ}$ angle, (d) right foot turn $90^{\circ}$ to power position, (e) turn into the circle, (f) follow-through essential for balance, (g) toeboard-foul lines. Students received no more than 7 points overall. The problem-solving test was scored by tallying the number of acceptable answers to each of the six problem-solving questions. Students were given one (1) point for each acceptable answer. Example of acceptable answers for the six questions included respectively, the following: (a) Moving backwards (Glide) instead rotation (Spin), (b) Shot against neck-under jaw, bend over $45^{\circ}-90^{\circ}$, back facing the direction of throwing, weight in one leg, body in T-shape, swinging leg behind support leg (c), Full extension of legs-trunk, throwing arm $45^{\circ}$ angle, arm/hand is pushed out with the thumb pointing downwards (d), Stand near of circle, shoulders opposite throwing direction, place shot against neck, throwing elbow pointed outward away from body, head up, shoulders level in same position, extend your left arm to the side, rotate your upper body one quarter turn to the right, bent right knee (e), Left arm pointed toward the target, left leg straight and right knee bent, right shoulder lower than the left and parallel with ground, weight on right foot (f), Not valid, valid, not valid. Students received no more than 6 points overall.

\section{RESULTS}

This was an experimental research study which used the cause-effect relationship in a group of variables. In the present study the instructional method was stated as an independent variable having two levels: narration and animation with concurrent audio narration and as dependent variable was children's shot put event comprehension.

Table 1 shows the number of participants, examined according to treatment condition, gender and age.

Table 1. Descriptive characteristics of subjects examined as treatment condition, gender and age.

\begin{tabular}{lcccc}
\hline \multicolumn{1}{c}{ Group } & \multicolumn{2}{c}{ Gender } & Age & Total \\
& Male & Female & & \\
\hline Narration & 8 & 7 & 10.5 & 15 \\
Animation with Narration & 6 & 9 & 10.6 & 15 \\
\hline
\end{tabular}

Statistical analysis included the use of T-test of Independent Samples. Statistical significant differences were found between the two treatment groups. Table 2 presents the mean scores and standard deviations for the two groups on retention and problem-solving test. Students in the animation with concurrent audio narration group performed better and remembered more ideas in the retention test $(\mathrm{M}=5.98, \mathrm{SD}=1.28)$, than students in the narration group $(\mathrm{M}=4.16, \mathrm{SD}=$ $1.17), \mathrm{t}(28)=1.89 \mathrm{p}<0.01$. Also during problem-solving test students in the animation with concurrent narration group produced more creative answers $(\mathrm{M}$ $=4.91, \mathrm{SD}=1.36)$ than did the narration group $(\mathrm{M}=$ $3.27, \mathrm{SD}=1.04) \mathrm{t}(28)=1.89 \mathrm{p}<0.01$.

Table 2. Mean Scores and Standard Deviations on Retention and Problem-Solving tests for the treatment groups.

\begin{tabular}{lllll}
\hline Group & \multicolumn{2}{c}{ Retention } & \multicolumn{2}{c}{ Problem-Solving } \\
\hline & M & SD & M & SD \\
\hline Narration & 4.16 & 1.17 & 3.27 & 1.04 \\
Animation with Narration & $5.98^{* *}$ & 1.28 & $4.91^{* *}$ & 1.36 \\
\hline
\end{tabular}

${ }^{* *} \mathrm{p}<0.01$ 


\section{DISCUSSION}

Multimedia instructional environments are widely recognized to improve the way and process of learning, comprehension and constructing knowledge (Mayer, 2009). Students in multimedia instructional environments are exposed to material in verbal-auditory (screen text, narration) and visual-pictoral forms (pictures, illustrations, videos and dynamic-animated pictures). Based on the principle of multimodality in a multimedia learning environment, knowledge may be presented in multiple ways (text, video, audio, image, interactive elements) making knowledge interest, curious and motivated (Johnson, Rickel, \& Lester, 2000; Luke, 2003).

Dual Code theory of Paivio (1986) gives emphasis on a mixed model of knowledge, where both visual (pictures) and verbal (words, sounds) information is used to represent knowledge. Animation is usually proceeded in the visual-pictorial channel and on the other hand narration is proceeded in the auditory-verbal channel of learning and communication (Lang, 1995). There is growing research base showing that students learn more deeply from well-designed multimedia presentations (pictures with words and sounds) than from traditional verbal-only messages (Mandl \& Levin, 1989; Mayer, 2009; Sweller, 1999).

The aim of the present study was to compare the effectiveness of two different teaching methods: animation with concurrent audio narration (pictures with words) and narration (words only) on students' comprehension and learning performance during Physical Education lesson. Results showed that teaching method of animation with concurrent audio narration improved students' comprehension better than method of narration. Students who received information and knowledge through pictures and words, improved their comprehension and knowledge significantly in the problem-solving test $(\mathrm{M}=4.91, \mathrm{SD}=1.36)$, than participants who received information through narration (words only) $(\mathrm{M}=3.27, \mathrm{SD}=1.04) \mathrm{t}(28)=1.89 \mathrm{p}<0.01$. This result is in agreement with some surveys indicatinge that learning performance is improved when information is presented in a mixed model (animation and narration) known as multimedia effect, rather than a single model (Mayer, \& Anderson, 1991; 1992;
Mayer, \& Gallini, 1990; Mayer, 1989; Mayer, 1997; Mayer, 1999a).

The result of the present study is also in agreement with Dual-Code theory (Paivio, 1986). In the present study animation with concurrent narration group received information through words and pictures (visual and verbal codes). This result is in agreement with the predictions of the integrated dual-code hypothesis and in disagreement with the predictions of single code and separate dual-code hypothesis. A possible reason is that we hypothesize, that teaching with pictures with words (digital animation) encourages students to build connection between their verbal and visual channel of communication and incoming information, which supports problem-solving and retention tests. Through words (narration) and pictures (animation) knowledge is constructed in student's working memory in a more effective way (Baddeley, 1998; Paivio, 1986).

The result of this study is also in agreement with the new trend and principle of teaching in schools, the principle of Multimodality and Multiliteracy (Cope \& Kalantzis, 2009; New London Group, 2000). It is well known that a multiple way of teaching methods and multiple teaching tools will create curiosity, motivate and improve knowledge, and make activities that children enjoy and respond to. Combining pictures with words (animation with narration), rather words only, is an effective method of teaching as students learn more deeply (Mayer, 2009).

Results of the present study are in accordance with results of other studies included Multimedia computer assisted instructions and their positive effect on students' achievement (Chu \& Chen, 2000; Kim, \& Lee, 2000; Siskos et al., 2005). The difference of the present study however with these studies is that those studies had a different methodology. It seems at least that Multimedia learning environment is useful during Physical Education lesson, particularly in teaching concepts and principles.

Future studies will be needed to explore the effectiveness of animation with or without concurrent narration method in lessons like Physical Education. As is mentioned, animation is a new trend, in accordance with a student oriented learning environment and more studies are needed to compare its effectiveness against other traditional and useful methods of teaching as narration. 


\section{CONCLUSION}

Results of this study indicate that students learn better from pictures with words, rather than from words. In the present study there is consistent empirical evidence for the contiguity principle of multimedia learning: students learn better when words and pictures are presented contiguously in time (digital animation). In our study digital animation group performed better in the

\section{REFERENCES}

1. Baddeley, A. (1998). Human Memory. Allyn and Bacon, Boston.

2. Bell, J.S. (2002). Narrative inquiry: more than just telling stories. TESOL Quarterly, 36(2), 207-213.

3. Betrancourt, M. (2005). The Animation and interactivity principles in Multimedia Learning. In Mayer, L.P. (Ed), The Cambridge Handbook of Multimedia Learning, Chapter 18 (p. 289). New York: Cambridge University Press.

4. Chu, H., \& Chen, W. (2000). Multimedia application to motor skill learning. Proceedings of ED-MEDIA 2000, Montreal, USA: July (2), 1257-1258.

5. Cope, B., \& Kalantzis, M.A. (2009). Multiliteracies: New Literacies, New Learning. Pedagogies: An International Journal, 4, 164-195.

6. Crafton, L.K., Brennan, M., \& Silvers, P. (2007). Critical inquiry and multiliteracies in a FirstGrade classroom. Language Arts, 84(6), 510-518.

7. Fiorentino, L.H., \& Castelli, D.M. (2005). Creating a virtual gymnasium: Providing an opportunity for perfect practice. Journal of Physical Education, Recreation and Dance, 76(4), 16-18.

8. Goran, M. I., \& Reynolds, K. (2005). Interactive multimedia for promoting physical activity (IMPACT) in children. Obesity Research, 13(4), 762771.

9. Hegarty, M., Kriz, S., \& Cate, C. (2003). The roles of mental animations and external animations in understanding mechanical systems. Cognition \& Instruction, 21(4), 325-360.

10. Johnson, W.L., Rickel, J.W., \& Lester, L. (2000). Animated pedagogical agents: Face to face interaction in interactive learning environments. question sheet rather than the narration group. It seems that learning in a multiple way of teaching (dynamic pictures with words) improves comprehension better, rather than a single way of teaching or a single channel information delivery system (narration) during teaching Physical Education. Future studies will need to investigate the effects of those two teaching methods: animation with or without words and narration in an athletic environment.

International Journal of Artificial Intelligence in Education, 11, 47-78.

11. Kay, H. R. (2012). Exploring the use of video podcasts in education: A comprehensive review of the literature. Computers in Human Behavior, $28,820-831$.

12. Kieras, D.E. (1992). Diagrammatic displays for engineered systems: Effects on human performance in interacting with malfunctioning systems. International Journal of Man-Machine Studies, 36, 861-895.

13. Kim, S., \& Lee, W. (2000). The effects of a hypermedia CAI system on the academic achievement of elementary school students in Korea. Proceedings of ED-MEDIA 2000 Montreal, Canada; June 26- July 1, (1), 491-495.

14. Kim, S., Yoon, M., Whang, S. M., Tversky, B., \& Morrison, J. B. (2007). The effect of animation on comprehension and interest. Journal of Computer Assisted Learning, 23, 260-270.

15. Lang, A. (1995). Defining audio/video redundancy from a limited-capacity information processing perspective. Communication Research, 22(1), $86-115$.

16. Luke, C. (2003). Pedagogy, connectivity, multimodality and interdisciplinarity. Reading Research Quarterly, 38(3), 397-403.

17. Mandl, H., \& Levin, J. R. (1989). Knowledge acquisition from text and pictures. Amsterdam: North Holland.

18. Mayer, R. E., \& Anderson, R. B. (1991). Animations need narrations: an experimental test of a dual-coding hypothesis. Journal of Educational Psychology, 83(4), 484-490. 
19. Mayer, R.E. (1989). Systematic thinking fostered by illustrations in scientific text. Journal of Educational Psychology, 81, 240-246.

20. Mayer, R.E. (1997). Multimedia learning: are we asking the right questions? Educational Psychologist, 32, 1-19.

21. Mayer, R.E. (1999a). Multimedia aids to problem-solving transfer. International Journal of Educational Research, 31, 611-623.

22. Mayer, R.E. (1999b). Research-based principles for the design of instructional messages. Document Design, 1, 7-20.

23. Mayer, R.E. (2003). The promise of multimedia learning: using the same instructional design methods across different media. Learning and Instruction, 13, 125-139.

24. Mayer, R.E. (2009). Multimedia learning ( $\left.2^{\text {nd }} e d\right)$. New York: Cambridge University Press.

25. Mayer, R.E., \& Anderson, R. B. (1992). The instructiveanimation:helpingstudentsbuildconnections between words and pictures in multimedia learning. Journal of Educational Psychology, 84(4), 444-452.

26. Mayer, R.E., \& Gallini, J. (1990). When is an illustration word ten thousand words? Journal of Educational Psychology, 82, 715-726.

27. Mayer, R.E., \& Moreno, R. (2003). Nine ways to reduce cognitive load in multimedia learning. Educational Psychologist, 38, 43-52.

28. Mayer, R.E., Hegarty, M., Mayer, S., \& Cambell, J. (2005). When static media promote active learning: annotated illustrations versus narrated animations in multimedia instruction. Journal of Experimental Psychology: Applied, 11(4), 256-265.

29. Metzler, M. (2011). Instructional models for Physical Education. Scottsdale, AZ: Holcomb Hathway Publishers.

30. Moreno, R., \& Mayer, R.E. (1999). Cognitive principles of multimedia learning: The role of modality and contiguity. Journal of Educational Psychology, 91, 358-368.

31. Narayanan, N.H., \& Hegarty, M. (2002). Multimedia design for communication of dynamic information. International Journal Human-Computer Studies, 57(4), 279-315.
32. New London Group. (2000). A pedagogy of multiliteracies: Designing social futures. In B. Cope \& Kalantzis (Eds.), Multiliteracies: Literacy learning and the design of social futures (pp. 9-38). South Yarra, VIC: Macmillan.

33. Paivio, A. (1986). Mental Representations: A Dual Coding Approach. New York: Oxford University Press.

34. Perez, E.C., \& White, M.A. (1985). Student evaluation of motivational and learning attributes of microcomputer software. Journal of Computer Based Instruction, 12, 39-43.

35. Rebetez, C., Sangin, M., Betrancourt, M., \& Dillenbourg, P. (2004). Effects of collaboration in the context of learning from animations. Proceedings of EARLI SIG meeting on Comprehension of Text and Graphics: Basic and Applied Issues, 9-11 September 2004, (pp. 187-192). Valencia (Spain),.

36. Rieber, L.P. (1990). Using computer animated graphics in science instruction with children. Journal of Educational Psychology, 82(1), 135140.

37. Sirikasem, P., \& Shebilske, W.L. (1991). The perception and metaperception of architectural designs communicated by video-computer imaging. Psychological Research-Psychological Forschung, 53, 113-126.

38. Siskos, A., Antoniou, P., Papaioannou, A., \& Laparidis, K. (2005). Effects of multimedia computer-assisted instruction (MCAI) on academic achievement in physical education of Greek primary students. Interactive Educational Multimedia, 10, 61-77.

39. Sweller, J. (1999). Instructional design in technological areas. Camberwell, Australia: ACER Press.

40. Walmsley, J. (2004). GCSE PE Analysis of Performance: Teacher Book. Folens Publisher, UK.

41. Young, H.I., \& Pass, F. (2015). Effects of Cueing by a Pedagogical Agent in an Instructional Animation: A Cognitive Load Approach. Educational Technology \& Society, 18(3), 153-160.

42. Zipes, J. (2013). When dreams come true: Classical Fairy Tales and their Tradition. $2^{\text {nd }}$ edition, Routledge, Taylor \& Francis Group, New York. 


\section{ANIMATION MIT SIMULTANER NARRATION GEGENÜBER NARRATION IM SPORTUNTERRICHT}

\section{Zusammenfassung:}

Ziel dieser Untersuchung war es, einen Vergleich der Effekte festzustellen, die zwei unterschiedliche Lehrmethoden auf das Verständnis der Schüler im Sportunterricht ausüben: Narration in Gegenüberstellung zu Animation mit simultaner Narration während des Unterrichts zum Thema Kugelstoßen. An dieser Untersuchung nahmen auf freiwilliger Basis 30 Kinder im Grundschulalter (Jungen und Mädchen) teil. Während des Experiments hörten (Narration) sie und schauten (Animation mit Narration) eine Präsentation über zwei Stile der Sportdisziplin Kugelstoßen an. Ein Test über Problemlösungen und ein Test für Wissensretention wurden für die Einschätzung des Verständnisses verwendet. Die Ergebnisse weisen darauf hin, dass die Schüler eine höhere Verständnisebene erzielten, wenn die Stile der Sportdisziplin Kugelstoßen mit Hilfe des Mischmodells (Animation mit Narration) dargestellt wurden. Die Gruppe, der die Inhalte durch Animation mit Narration dargestellt wurden, erzielte bessere Ergebnisse als die Gruppe, der die Inhalte nur durch Narration präsentiert wurden - der Test der Problemlösung $(M=4,91, S D=1,36)$, der Test der Wissensretention ( $M$ $=5,98, \mathrm{SD}=1,28) \tau(28)=1,89 \Pi<0,01$. Die Schlussfolgerung weist darauf hin, dass in einem kontinuierlichen Sportunterricht Bilder gemeinsam mit Worten eine effizientere Lehrmethode im Vergleich zur Methode, in der nur Worte verwendet werden, darstellen.

Schlüsselwörter: THEORIE DER DOPPELTEN KODIERUNG / BILDER / WORTE / KUGELSTOßVERANSTALTUNG

Received: 07.09.2016.

Accepted: 02.11.2016.

(c) 2016 The Author. Published by Physical Culture (www.fizickakultura.com). This article is an open access article distributed under the terms and conditions of the Creative Commons Attribution license (http://creativecommons. org/licenses/by/3.0/rs/).

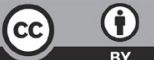




\title{
АНИМАЦИЈА СА СИМУЛТАНОМ НАРАЦИЈОМ НАСУПРОТ НАРАЦИЈИ У НАСТАВИ ФИЗИЧКОГ ВАСПИТАҢА
}

\author{
Панагиотис Иоану르, Пантелеимон Бакиртзоглоу² \\ ${ }^{1}$ Универзитет у Патри, Департман основног васпитања, Патра, Грчка \\ ${ }^{2}$ Универзитет Аристотел у Солуну, Школа физичког васпитања и спортских наука, Солун, Грчка
}

\begin{abstract}
Сажетак
Циљ овог истраживања је био да се упореде ефекти које две различите наставне методе имају на разумевање код ученика на часу физичког васпитања: нарација насупрот анимацији са симултаном нарацијом током наставе о бацању кугле. У овом истраживању добровољно је учествовало тридесеторо деце основношколског узраста (дечаци и девојчице). Приликом експеримента ученици су слушали (нарација) и гледали (анимација са нарацијом) презентацију о два стила бацања кугле. Тест решавања проблема и тест ретенције знања су коришћени за процену разумевања. Резултати показују да су ученици боље разумели када су стилови бацања кугле били представљени помоћу мешовитог модела (група анимације и нарације), него што је то био случај са јединственим моделом (нарација). Група којој је била представљена анимација са симултаном нарацијом била је успешнија од групе којој је представљена само нарација на тесту решавања проблема $(\mathrm{M}=4.91, \mathrm{CД}=1.36)$, као и на тесту ретенције знања $(\mathrm{M}=5.98, \mathrm{CД}=1.28) \mathrm{T}(28)=1.89 \Pi<0.01$. Закључак значајан за наставу је да су слике заједно са речима ефикаснији метод наставе када се континуирано појављују током времена, него само речи у настави физичког васпитања.
\end{abstract}

Кључне речи: ТЕОРИЈА ДВОСТРУКИХ КОДОВА / СЛИКЕ / РЕЧИ / БАЦАЧКИ ДОГАЂАЈ

\section{УВОД}

Нове технологије, образовни софтверски програми и мултимедијална наставна окружења примењују и заснивају се на мултимодалности као наставној методи (Crafton, Brennan, \& Silvers, 2007). Мултимодалност се заправо односи на систем учења помоћу вишеструких дидаткичких наставних материјала: визуелних средстава попут слова, графика и слика (статичних или анимираних), аудио материјала попут гласова и звукова, као и кинетичких средстава попут ручног рада или ручног решавања проблема (Cope, \& Kalantzis, 2009).

Према Мајеру и Морену (Mayer, \& Moreno, 2003), у мултимедијалном наставном окружењу информације се представљају у два или више модалитета, визуелном (слике, прикази, графици) и аудитивном (звукови, речи). Помоћу технологије, информације и знања се представљају у вишеструким модалитетима путем компјутерских динамичних медија као што су анимације и аудио записи (Kay, 2012; Narayanan, \& Hegarty, 2002). Мултимедијално учење се одвија када ученици изграде менталне представе од слика и речи које им се представљају. Ученици уче много темељније уз комбинацију речи и слика него само уз речи, што је познато као мултимедијални ефекат (Mayer, 2003).

Когнитивна теорија мултимедијалног учења позната као теорија двоструких кодова, коју је унапредио Паивио (Paivio, 1986) се заснива на главној претпоставци да постоје два одвојена канала за обраду информација (аудитивни и визуелни). У складу са овом теоријом, речи и слике активирају независне визуелне и вербалне кодове. Према теорији двоструких кодова, нарација (вербална) се обрађује у аудитивно-вербалном каналу. На неким часовима, попут историје, језика, географије и верске наставе, нарација је најприсутнији и најефикаснији стил или наставна 
метода која има за циљ да мотивише ученике да изграђују знања (Bell, 2002; Zipes, 2013). Међутим, утицај нарације на успех ученика у учењу је контроверзан. Постоје емпиријски докази да нарација нема позитван утицај на успех ученика у учењу. Резултати показују да када ученици слушају или само читају објашњења која им се представљају као речи нису у стању да запамте већину кључних појмова (Mayer, 1997; 1999a; 1999b).

Анимација (визуелна) се, према теорији двоструких кодова, обрађује у визуелном каналу. Један од главних разлога растуће популарности анимираних графика је, изгледа, уверење да је анимација интересантнија, естетски привлачнија и, стога, у већој мери мотивише када се користи као средство у педагогији (Kim et al., 2007; Young, \& Pass, 2015). Према неким ауторима, деца више воле анимацију због њене атрактивности (Perez, \& White, 1985; Sirikasem, \& Shebilske, 1991). Meђутим, утицај који анимација има на разумевање код ученика је споран (Betrancourt, 2005; Kim et al., 2007). Неке студије су показале значајне и стварне ефекте и побољшања који су, помоћу графика са анимацијом, остварени у учењу, са друге стране, неке студије су показале супротне резултате, као и штетан утицај на успешност у учењу. Неки основни проблеми експеримената између графика са или без анимације су у томе што у студијама које су упоређивале анимације нису примењени еквивалентни поступци (Betrancourt, 2005; Mayer, Hegarty, Mayer, \& Cambell, 2005).

Многи аутори истражују упоређивање анимације (слика) и нарације (речи) на разним часовима попут физике, математике, геометрије, биологије, астрономије и механике (Kieras, 1992; Hegarty, Kriz, \& Gate, 2003; Rebetez et al., 2004; Rieber, 1990). Штавише, поређење анимације са симултаном нарацијом (слике са речима) и нарације (речи) је показало да је мешовити информациони модел (анимација са нарацијом) ефикаснији од јединственог информационог модела (само нарација) (Mayer, 1989; Mayer, \& Gallini, 1990; Mayer, \& Anderson, 1992; Moreno, \& Mayer, 1999). Ученици боље уче када се речи и слике представљају истовремено, него када се само речи или само слике користе као наставне методе (Moreno, \& Mayer, 1999).

У настави физичког васпитања се користе разноврсни наставни стилови преименовани из рада Мостона и Ешворта (Metzler, 2011). Наставне методе могу обухватити предавачку методу (речи или нарација) као и методу визуелизације или опсервације (модели, видео снимци, упутства помоћу рачунара или анимација). Нарација на часовима физичког васпитања се често користи у свим узрастима и за све нивое физичких перформанси, како за учење нових вештина тако и као метод давања упутстава. Употреба анимације у настави физичког васпитања се одвија методом приказа или употребом модела-обрасца за учење, побољшање или кориговање нових вештина. Међутим, наставне методе нарације и анимације помоћу мултимедија се користе у основним, средњим, високим школама, као и на факултетима како би се побољшала мотивација ученика и студената, као и когнитивни и физички учинак кроз омогућавање активног и експерименталног учења (Fiorentino \& Castelli, 2005; Goran \& Reynolds, 2005). Компјутерска технологија и мултимедијална настава у простору су постали саставни део физичког васпитања (Siskos, Antoniou, Papaioannou, \& Laparidis, 2005). У данашњој литератури недостају испитивања ефеката који се постижу сликама са речима (анимација са нарацијом) насупрот само речима (нарација) у учинку ученика на часу физичког васпитања.

Стога је циљ овог истраживања био да се упореди ефикасност анимације са симултаном нарацијом (слике са речима) и нарације (само речи) и њихови утицаји на учинак ученика током наставе на часу физичког васпитања.

\section{МЕТОД}

\section{Узорак испитаника}

Тридесеторо $(\mathrm{N}=30)$ деце петог и шестог разреда из 4 државне основне школе из солунске префектуре (Грчка) је изабрано за потребе овог истраживања путем методе случајног узорка. Деца су пријавила низак ниво претходног искуства у гледању и извођењу дисциплине бацања кугле, услед изостанка наставних садржаја о бацању кугле (клизни или ротациони стил бацања) у наставном плану и програму наставе физичког васпитања током ове и претходних година. Половина учесника је била у групи нарације (само речи), а друга половина испитаника је била у гру- 
пи анимације са симултаном нарацијом (слике са речима). Групе су формиране методом случајног избора.

\section{Материјали и опрема}

Штампани материјал за попуњавање се састојао од упитника за испитанике, једне стране теста који је садржао питања и могућа објашњења - одговоре (тест решавања проблема) и теста ретенције знања. У упитнику се тражило да ученици назначе године старости и пол. Упитник је такође имао и скалу за процену знања о бацању кугле где је од ученика тражено да на петостепеној скали ( 1 = веома мало, 3 = осредње, $5=$ веома пуно) оцене свој ниво знања о бацању кугле и да штиклирају сваку од пет тачака које се односе на дисциплину бацања кугле које су им представљене (нпр. "Познајем вештине бацања у атлетици”, “Бацао/ла сам тежак предмет сферног облика”, “Познајем стилове бацања кугле", “Знам када је хитац исправан или није”, “Знам фазе стилова бацања кугле”).

Тест решавања проблема је садржао следећих шест (6) питања: “Која је разлика између клизног и ротационог стила?", “Која је техника клизног стила током припремне фазе?”, “Која је техника клизног стила у бацању кугле током фазе избачаja?", “Која је техника кружног стила током максималног напора?”, “Шта ће се догодити ако током извођења покрета бацања спортиста дотакне врх гвозденог прстена или баци куглу на линију преступа или изван ње?”. Тест ретенције знања је садржао следећа штампана упутства: "Молимо да опишете писмено клизни и ротациони стил бацања кугле”.

Компјутерски материјал се састојао од две анимације о дисциплини бацања кугле (клизна и ротациона техника у бацању кугле), у трајању од око 2 минута свака. Мултимедијални програми су састављени помоћу Adobe Reader 12 Верзија (за оперативни систем Windows). У првој анимацији је била приказана монохроматска фигура спортисте током извођења клизна технике у бацању кугле и намера је била да се опишу основне фазе овог стила бацања, као и нека основна правила овог спорта заједно са симултаном нарацијом која је била подељена у 12 сегмената (Слике 1-6). Друга анимација је приказивала монхроматску фигуру спортисте током извођења ротационе технике у бацању кугле, а циљ је био да се опишу основне фазе овог стила бацања, као и нека основна правила овог спорта заједно са симултаном нарацијом која је била подељена на 11 сегмената (Слике 7-12). Наративни материјал се састојао од описа ротационе технике у бацању кугле од отприлике 325 речи, а циљ је био да се опишу њене основне фазе и правила и опис ротационе технике бацања кугле у око 319 речи (Walmsley, 2004). Нарације су представљене дигитализованим мушким гласом и трајале су око 2 минута свака. Током нарације сва деца су добила кратка упутства да се утишају и сконцентришу на глас истраживача.

Следи опис клизне технике са одговарајућом нарацијом.

Клизна техника у бацању кугле. Припремна фаза: поставите куглу десном руком уз врат и испод браде, лева потпорна нога у усправном положају, савијени у претклон од $45-90^{\circ}$, леђима окренути правцу бацања, тежина тела на једној нози, тело у облику слова Т, замајна нога се из испруженог положаја доводи у заножење иза стајне ноге (Слика 1).

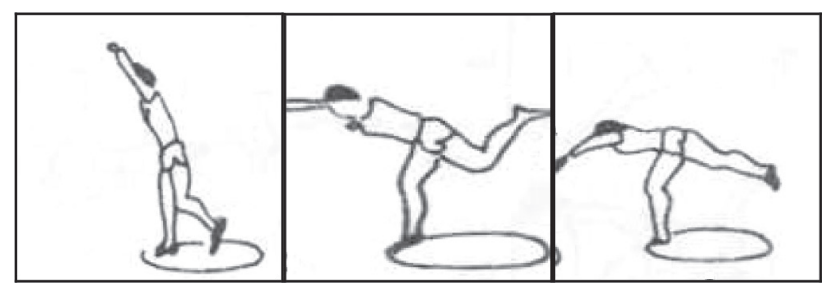

Слика 1. Припремна фаза

Клизна фаза: стајна нога из усправног долази у савијени положај, тело се пребацује уназад, замајна нога се помера ниско према ивици круга, стајна нога у заножењу одржавајући круг, лево и десно стопало брзо једно за другим долазе у контакт са тлом (Слика 2). Максимални напор: тежина тела се одржава на десном стопалу, пета десног стопала и прсти левог стопала су у равни, линија рамена је иза линије кука, глава и лева рука су окренуте ка задњем делу круга, десна нога је окренута $90^{\circ}$ према предњем делу круга за избачај (Слика 3).

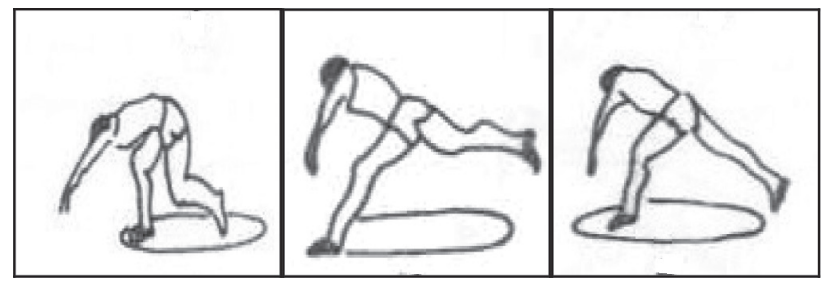

Слика 2. Клизна фаза 


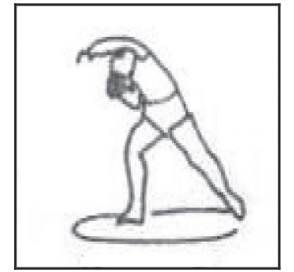

Слика 3. Фаза максималног напора

Фаза избачаја: Када десна нога додирне средину круга, одмах се окреће и подиже, тежина тела се пребацује са десне стране на леву ногу, лева нога се снажно спушта у круг, тело се исправља навише, лева рука и лева страна трупа се сабијаjу што је више могуће, десни лакат се подиже и гура напред према сектору, десна нога се окреће и подиже (Слика 4). Фаза сувања кугле: избачај руком почиње након потпуног испружања ногу и трупа, лева рука је подупрта и држи се уз труп, рука којом се баца је је подигнута до угла од око $45^{\circ}$, рука/шака се избацује палцем окренутим на доле, кугла се ослобађа унапред уз гурање десном ногом (Слика 5).

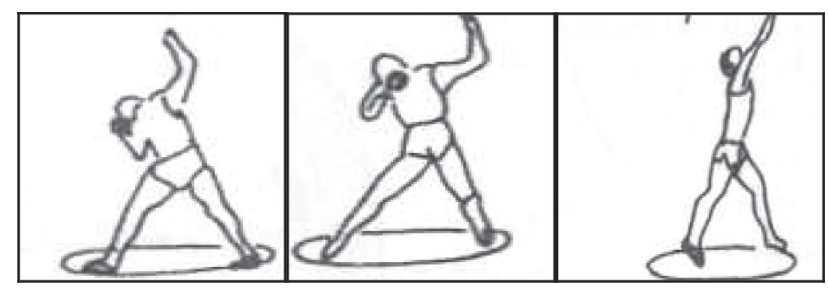

Слика 4. Фаза избачаја

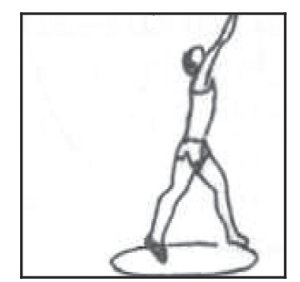

Слика 5. Фаза сувања

Фаза одржавања равнотеже (Слика 6): контакт стопалима са тлом би требало одржати што је дуже могуће (експлозивни покрет ногом може довести до тога да се при ослобађању кугле ноге одвоје од тла), добар наставак покрета је кључан за равнотежу, хитац није исправан ако спортиста додирне врх ивице круга или згази изван круга нити ако кугла падне изван граничних линија на десну или леву страну, али је исправан ако падне на саму границу (линију преступа).

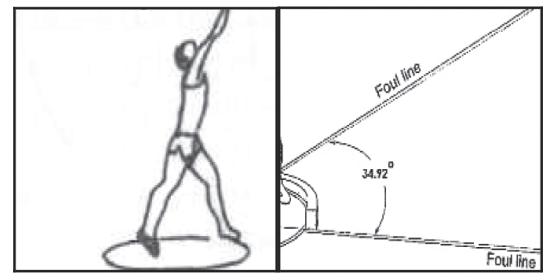

Слика 6. Фаза одржавања равнотеже

Следи опис ротационе технике са одговарајућом нарацијом

Припремна фаза: станите у близину круга, рамена су окренута супротно правцу бацања, поставите куглу коренима прстију уз врат (десноруки бацачи), лакат руке којом се баца у одручењу, глава подигнута, линија рамена у истом положају, испружите леву руку у страну, ротирајте горњи део тела четврт круга у десно, савијте десно колено (Слика 7). Ротациона фаза (улаз 1\&2): преместите тежину на леву страну како се окрећете, окрените се у круг, затим окрените лево стопало, мало савијте лево колено, поравнајте лево стопало, пребаците тежиште на леву страну, започните издизање десног стопала, спустите десно стопало у средину круга, ротирајте се и окрените леву ногу (Слика 8).

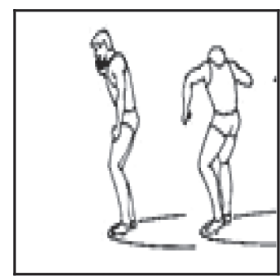

Слика 7. Припремна фаза

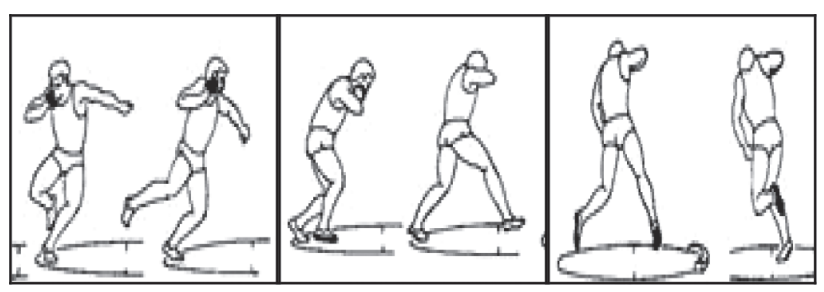

Слика 8. Ротациона фаза (улаз 1 и 2)

Ротациона фаза (покрет 1\&2): наставите замахивање десне ноге док се не спусти у центар круга, десни лакат окренут ка циљу, десно колено савијено, подигните лево колено и заокрените га ка предњем делу круга, лева рука се испружа ка циљу док се лево раме подиже (Слика 9). Фаза максималног напора: лева рука је подигнута ка циљу, лева нога је опружена, а десно колено савијено, 
десно раме је ниже од левог и паралелно са подлогом, тежина је на десном стопалу (Слика 10).

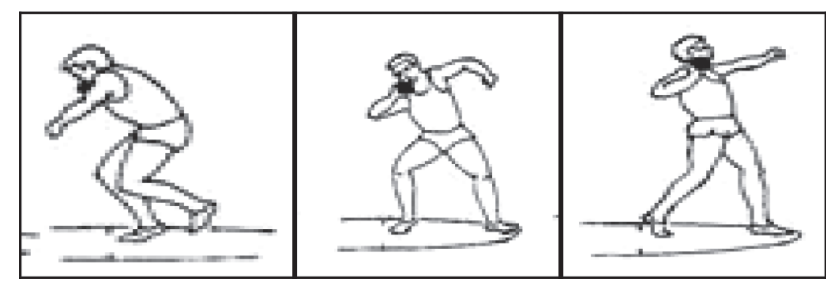

Слика 9. Ротациона фаза (покрет 1\&2)

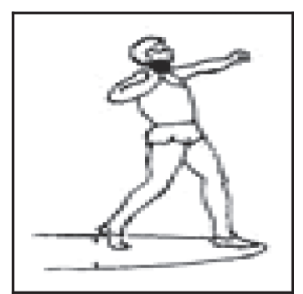

Слика 10. Фаза максималног напора

Фаза сувања: лева рука је подигнута ка циљу, лева нога је опружена, а десно колено савијено, десно раме је ниже у односу на лево и паралелно са подлогом, рука којом се баца савијена до угла од око $45^{\circ}$, тежина је на десном стопалу, кугла се ослобађа напред уз гурање левом ногом (Слика 11). Фаза одржавања равнотеже (Слика 12): док гурате десним стопалом подигните ногу и окрените се у лево, када десно стопало додирне тло поскочите и наставите да се окрећете, добар наставак покрета је кључан за равнотежу. Хитац није исправан ако спортиста додирне врх ивице круга или згази изван круга, нити ако кугла падне изван граничних линија у леву или десну страну, али је исправан ако кугла падне на саму границу (линију преступа).

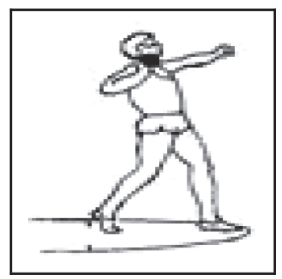

Слика 11. Фаза сувања

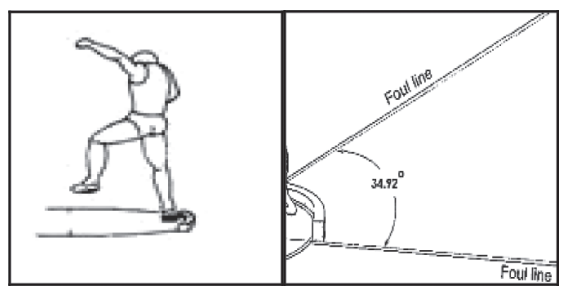

Слика 12. Фаза одржавања равнотеже
Уређаји су се састојали од једног Тошиба Сателит С55-В5298 лаптоп рачунара са монитором од 15 инча, повезаног са пројектором EPOSN EH-TW570. Слушалице FRISBY FS-75NU су биле прикључене у аудио излаз Тошиба лаптоп рачунара. Тестови су мерени помоћу штоперице.

\section{Поступак}

Пет дана пре мерења деца и родитељи су обавештени, и писменим и усменим путем, о циљевима и обиму истраживања. Родитељи деце су добили обавештења на листу папира. У овом обрасцу је јасно назначено да је истраживање добровољно и да дете може одустати у сваком тренутку. Сагласност је прибављена у складу са политиком Етичког комитета Универзитета Аристотел у Солуну.

Мерења су почињала рано ујутру (09.00 часова). Ученици су случајним одабиром распоређени у групе (група нарације и група анимације са симултаном нарацијом). Упућени су да ће чути кратку нарацију (група нарације) о клизној и ротационој техници бацања кугле и погледати кратку мултимедијалну презентацију (анимација са симултаном нарацијом) о техникама бацања кугле, затим да треба да обрате пажњу, као и да након презентација треба да одговоре на нека питања у вези са материјалом. Прво, ученици су попуњавали упитник за испитанике оцењујући сами себе. Друго, након добијања кратких упутстава, ученици (група нарације) су слушали нарацију о техникама бацања кугле изведену од стране истраживача три пута, а друга половина ученика (анимација са симултаном аудио нарацијом) је гледала анимацију са нарацијом о техникама бацања кугле, три пута такође. Нарација и презентације анимације трајале су око 2 минута свака. Tреће, ученици су писали одговоре на проблемске задатке у трајању од 5 минута. Четврто, након решавања проблема, ученици су почели да решавају тест ретенције знања. Ученицима је дато 5 минута да напишу што је више могуће решења на свако питање. Током овога, ученици нису могли да се врате на претходно питање нити да пређу на наредно питање.

У упитнику ученици су оценили своје знање о бацању кугле као просечно и назначили да су имали мало искуства на терену са овим догађајем. Тест ретенције знања је оцењиван утврђивањем колико је од седам кључних појмова укључено у 
програм. Један (1) поен је додељен за сваки од следећих појмова: (а) тело у облику слова Т (клизни стил), ротација (кружни стил), (ठ) кугла постављена уз врат-испод браде, (ц) рука којојм се баца савијена до угла од $45^{\circ}$, (д) десно стопало окренуто $90^{\circ}$ до максималног напора, (е) окретање у круг-ротирање, (ф) наставак кретања од суштинске важности за равнотежу, (г) линије приступа - ивица круга. Ученици су добијали највише 7 поена укупно. Тест решавања проблема је оцењиван бележењем броја прихватљивих одговора на свако од шест проблемских питања. Ученици су добијали један (1) поен за сваки прихватљив одговор. Пример прихватљивих одговора за свако од шест питања редом укључивао је следеће: (а) Кретање уназад (клизни стил) уместо ротације (ротациони стил), (б) Кугла уз врат-испод браде, тело савијено у претклон у углу од $45^{\circ}-90^{\circ}$, леђа окренута правцу бацања, тежина на једној нози, тело у облику слова T, замајна нога иза стајне ноге, (ц) Потпуно истезање ногу - трупа, рука којом се ठаца савијена у углу од $45^{0}$, рука/шака се гура напред са палцем упртим на доле, (д) Ста- ните у близини круга, рамена окренута супротно правцу бацања, ставите куглу уз врат, лакат руке којом се баца у одручењу, глава подигнута, рамена у истој равни, одручите леву руку, ротирајте горњи део тела четврт круга у десно, савијте десно колено, (е) Лева рука уперена ка циљу, лева нога исправљена и десно колено савијено, десно раме ниже од левог и паралелно са тлом, тежина на десном стопалу, (ф) Није исправно, исправно, није исправно. Ученици су добијали највише 6 поена укупно.

\section{РЕЗУЛТАТИ}

У овом истраживању, наставна метода је наведена као независна варијабла која има два нивоа: нарацију и анимацију са симултаном аудио нарацијом, а као зависна варијабла узето је разумевање догађаја бацања кугле које су деца показала.

Табела 1 показује број учесника, испитаних у складу са условима испитивања, полу и узрасту.

Табела 1. Дескриптивне карактеристике испитаника који су испитивани према условима испитивања, полу и узрасту.

\begin{tabular}{|c|c|c|c|c|}
\hline \multirow{2}{*}{ Група } & \multicolumn{2}{|c|}{ Пол } & \multirow[t]{2}{*}{ Узраст } & \multirow[t]{2}{*}{ Тотал } \\
\hline & Дечаци & Девојчице & & \\
\hline Нарација & 8 & 7 & 10.5 & 15 \\
\hline Анимација са нарацијом & 6 & 9 & 10.6 & 15 \\
\hline
\end{tabular}

Статистичка анализа је обухватала коришћење Т-теста независног узорка. Статистички значајне разлике су пронађене између две испитиване групе. Табела 2 приказује средње вредности и стандрадне девијације за две групе у тестовима решавања проблема и ретенције знања. Ученици у групи којој је представљена анимација са симултаном аудио нарацијом су били успешнији и запамтили су више појмова на тесту ретенције знања $(\mathrm{M}=5.98$, СД = 1.28), него ученици у групи којој је била представљена само нарација (М $=4.16$, СД = 1.17), $\mathrm{t}(28)=1.89 \mathrm{p}<0.01$. Такође, на тесту решавања проблема, ученици у групи анимације са симултаном аудио нарацијом су давали креативније одговоре $(\mathrm{M}=4.91, \mathrm{CД}=1.36)$ него ученици из групе нарације $(\mathrm{M}=3.27$, СД $=1.04)$ $\mathrm{t}(28)=1.89 \mathrm{p}<0.01$.

Табела 2. Средње вредности и стандрадне девијације у тестовима решавања проблема и ретенције знања за испитиване групе.

\begin{tabular}{lcccc}
\hline Група & \multicolumn{2}{c}{ Ретенција } & \multicolumn{2}{c}{ Решавање проблема } \\
\hline & $\mathbf{M}$ & $\mathbf{C Д}$ & М & СД \\
\hline Нарација & 4.16 & 1.17 & 3.27 & 1.04 \\
Анимација са нарацијом & $5.98^{* *}$ & 1.28 & $4.91^{* *}$ & 1.36 \\
\hline
\end{tabular}




\section{ДИСКУСИЈА}

Мултимедијална наставна окружења су широко призната у побољшању начина и процеса учења, разумевања и изграђивању знања (Mayer, 2009). Ученици у мултимедијалним наставним окружењима су изложени материјалу у вербално-аудитивним (текст на екрану, нарација) и визуелно-сликовним облицима (слике, илустрације, видео снимци и динамички анимиране слике). На основу принципа мултимодалности у мултимедијалном наставном окружењу, знања се могу представити на више начина (текст, видео, аудио, слика, интерактивни елементи) што чини стицање знања интересантним, а ученике радозналим и мотивисаним (Johnson, Rickel, \& Lester, 2000; Luke, 2003).

Теорија двоструких кодова коју је развио Паивио (Paivio, 1986) ставља нагласак на мешовити модел знања, где се и визуелне информације (слике) и вербалне информације (речи, звукови) користе како би се представило знање. Анимација се обично обрађује у визуелно-сликовном каналу, а нарација се, са друге стране, обрађује у аудитивно-вербалном каналу учења и комуникације (Lang, 1995). Растућа истраживачка база показује да ученици стичу дубља знања кроз добро дизајниране мултимедијалне презентације (слике са речима и звуковима) него кроз традиционалне поруке које су искључиво вербалне (Mandl, \& Levin, 1989; Mayer, 2009; Sweller, 1999).

Циљ овог истраживања био је да се упореди ефикасност две различите наставне методе: анимације са симултаном аудио нарацијом (слике са речима) и нарације (само речи) и њихови утицаји на разумевање и успешност у учењу од стране ученика на часовима физичког васпитања. Резултати показују да наставна метода анимације са симултаном аудио нарацијом у већој мери побољшава разумевање код ученика него метода нарације. Ученици који су информације и знања примали кроз речи и слике, унапредили су своје разумевање и знање при изради теста решавања проблема у значајној мери $(\mathrm{M}=4.91$, СД = 1.36$)$, у односу на учеснике који су информације примали путем нарације (само речи) $(\mathrm{M}=3.27, \mathrm{CД}=$ 1.04) $\mathrm{t}(28)=1.89 \mathrm{p}<0.01$. Овај резултат је у складу са неким истраживањима која указују на то да се успешност у учењу побољшава када се информације представљају путем мешовитог модела (анимација и нарација) познатог и као мулитмедијални ефекат, него што је то случај са једноструким моделом (Mayer, \& Anderson, 1991; Mayer, \& Anderson, 1992; Mayer, \& Gallini, 1990; Mayer, 1989; Mayer, 1997; Mayer, 1999a).

Резултати овог истраживања су такође у складу са теоријом двоструких кодова (Paivio, 1986). У овом истраживању група којој је представљена анимација са симултаном нарацијом је примала информације кроз речи и слике (визуелни и верठални кодови). Овај резултат је у складу са предвиђањима интегрисане претпоставке двоструких кодова, а није у складу са предвиђањима претпоставке једноструког кода и одвојених двоструких кодова. Могући разлог је то што ми претпостављамо да настава кроз слике са речима (дигитална анимација) подстиче ученике да изграђују везу између свог вербалног и визуелног канала комуникације и надолазеће информације, што помаже при решавању тестова решавања проблема и тестова ретенције знања. Кроз речи (нарација) и слике (анимација) знање се изграђује у радној меморији ученика на ефикаснији начин (Baddeley, 1998; Paivio, 1986).

Резултати ове студије су такође у складу са новим трендом и принципом наставе у школама, принципом мултимодалности и мултиписмености (Cope, \& Kalantzis, 2009; New London Group, 2000). Добро је познато да ће вишеструке наставне методе и вишеструка наставна средства развити радозналост и мотивисаност и побољшати знање, учинити да деца уживају у активностима, као и да на њих реагују. Комбиновање слика са речима (анимација са нарацијом) је ефикаснија наставна метода него саме речи, пошто ученици стичу дубља знања (Mayer, 2009).

Резултати овог истраживања су у складу са резултатима других студија обухваћеним у настави уз помоћ мултимедија и компјутера и позитивним ефектима које она има на постигнућа ученика (Chu, \& Chen, 2000; Kim, \& Lee, 2000; Siskos, Antoniou, Papaioannou, \& Laparidis, 2005). Meђyтим, разлика овог истраживања и тих студија је у томе што су те студије примењивале другачију методологију. Изгледа, бар, да је мултимедијално наставно окружење корисно на часовима физичког васпитања, нарочито у настави концепта и принципа.

У будућности ће бити потребно да студије истраже ефикасност методе анимације са или без 
симултане нарације на часовима физичког васпитања. Као што је напоменуто, анимација је нови тренд, у складу са наставним окружењем које је окренуто ка ученику, и биће потребно још студија које ће упоредити њену ефикасност у односу на друге традиционалне и корисне методе наставе као што је нарација.

\section{ЗАКЉУЧАК}

Резултати овог истраживања показују да ученици боље уче кроз слике са речима, него само кроз речи. У овом истраживању постоје конзистентни емприријски докази за принцип непре-

\section{ЛИТЕРАТУРА}

1. Baddeley, A. (1998). Human Memory. Allyn and Bacon, Boston.

2. Bell, J.S. (2002). Narrative inquiry: more than just telling stories. TESOL Quarterly, 36(2), 207-213.

3. Betrancourt, M. (2005). The Animation and interactivity principles in Multimedia Learning. In Mayer, L.P. (Ed), The Cambridge Handbook of Multimedia Learning, Chapter 18 (p. 289). New York: Cambridge University Press.

4. Walmsley, J. (2004). GCSE PE Analysis of Performance: Teacher Book. Folens Publisher, UK.

5. Goran, M.I., \& Reynolds, K. (2005). Interactive multimedia for promoting physical activity (IMPACT) in children. Obesity Research, 13(4), 762-771.

6. Zipes, J. (2013). When dreams come true: Classical Fairy Tales and their Tradition. $2^{\text {nd }}$ edition, Routledge, Taylor \& Francis Group, New York.

7. Young, H.I., \& Pass, F. (2015). Effects of Cueing by a Pedagogical Agent in an Instructional Animation: A Cognitive Load Approach. Educational Technology \& Society, 18(3), 153-160.

8. Johnson, W.L., Rickel, J.W., \& Lester, L. (2000). Animated pedagogical agents: Face to face interaction in interactive learning environments. International Journal of Artificial Intelligence in Education, $11,47-78$. кидности мултимедијалног учења: ученици боље уче када се слике и речи представљају континуирано током времена (дигитална анимација). У нашем истраживању група којој је била представљена дигитална анимација успешније је одговорила на питања из упитника него група којој је била представљена нарација. Изгледа да учење путем више наставних метода (динамичке слике са речима) побољшава разумевање боље него јединствени наставни метод или једноструки систем канала за испоруку информација (нарација) у настави физичког васпитања. Биће потребно да будућа истраживања испитају ефекте ове две наставне методе: анимације са или без речи и нарације у спортском окружењу.

9. Kay, H. R. (2012). Exploring the use of video podcasts in education: A comprehensive review of the literature. Computers in Human Behavior, 28, $820-831$.

10. Kieras, D.E. (1992). Diagrammatic displays for engineered systems: Effects on human performance in interacting with malfunctioning systems. International Journal of Man-Machine Studies, 36, 861-895.

11. Kim, S., \& Lee, W. (2000). The effects of a hypermedia CAI system on the academic achievement of elementary school students in Korea. Proceedings of ED-MEDIA 2000 Montreal, Canada; June 26- July 1, (1), 491-495.

12. Kim, S., Yoon, M., Whang, S. M., Tversky, B., \& Morrison, J. B. (2007). The effect of animation on comprehension and interest. Journal of Computer Assisted Learning, 23, 260-270.

13. Lang, A. (1995). Defining audio/video redundancy from a limited-capacity information processing perspective. Communication Research, 22(1), 86-115.

14. Luke, C. (2003). Pedagogy, connectivity, multimodality and interdisciplinarity. Reading Research Quarterly, 38(3), 397-403.

15. Mandl, H., \& Levin, J. R. (1989). Knowledge acquisition from text and pictures. Amsterdam: North Holland. 
16. Mayer, R. E., \& Anderson, R. B. (1991). Animations need narrations: an experimental test of a dual-coding hypothesis. Journal of Educational Psychology, 83(4), 484-490.

17. Mayer, R.E. (1989). Systematic thinking fostered by illustrations in scientific text. Journal of Educational Psychology, 81, 240-246.

18. Mayer, R.E. (1997). Multimedia learning: are we asking the right questions? Educational Psychologist, 32, 1-19.

19. Mayer, R.E. (1999a). Multimedia aids to problem-solving transfer. International Journal of Educational Research, 31, 611-623.

20. Mayer, R.E. (1999b). Research-based principles for the design of instructional messages. Document Design, 1, 7-20.

21. Mayer, R.E. (2003). The promise of multimedia learning: using the same instructional design methods across different media. Learning and Instruction, 13, 125-139.

22. Mayer, R.E. (2009). Multimedia learning ( $2^{\text {nd }} e d$ ). New York: Cambridge University Press.

23. Mayer, R.E., \& Anderson, R. B. (1992). The instructive animation: helping students build connections between words and pictures in multimedia learning. Journal of Educational Psycholo$g y, 84(4), 444-452$.

24. Mayer, R.E., \& Gallini, J. (1990). When is an illustration word ten thousand words? Journal of Educational Psychology, 82, 715-726.

25. Mayer, R.E., \& Moreno, R. (2003). Nine ways to reduce cognitive load in multimedia learning. Educational Psychologist, 38, 43-52.

26. Mayer, R.E., Hegarty, M., Mayer, S., \& Cambell, J. (2005). When static media promote active learning: annotated illustrations versus narrated animations in multimedia instruction. Journal of Experimental Psychology: Applied, 11(4), 256-265.

27. Metzler, M. (2011). Instructional models for Physical Education. Scottsdale, AZ: Holcomb Hathway Publishers.

28. Moreno, R., \& Mayer, R.E. (1999). Cognitive principles of multimedia learning: The role of modality and contiguity. Journal of Educational Psychology, 91, 358-368.
29. Narayanan, N.H., \& Hegarty, M. (2002). Multimedia design for communication of dynamic information. International Journal Human-Computer Studies, 57(4), 279-315.

30. New London Group. (2000). A pedagogy of multiliteracies: Designing social futures. In B. Cope \& Kalantzis (Eds.), Multiliteracies: Literacy learning and the design of social futures (pp. 9-38). South Yarra, VIC: Macmillan.

31. Paivio, A. (1986). Mental Representations: A Dual Coding Approach. New York: Oxford University Press.

32. Perez, E.C., \& White, M.A. (1985). Student evaluation of motivational and learning attributes of microcomputer software. Journal of Computer Based Instruction, 12, 39-43.

33. Rebetez, C., Sangin, M., Betrancourt, M., \& Dillenbourg, P. (2004). Effects of collaboration in the context of learning from animations. Proceedings of EARLI SIG meeting on Comprehension of Text and Graphics: Basic and Applied Issues, 9-11 September 2004, (pp. 187-192). Valencia (Spain),.

34. Rieber, L.P. (1990). Using computer animated graphics in science instruction with children. Journal of Educational Psychology, 82(1), 135140.

35. Sirikasem, P., \& Shebilske, W.L. (1991). The perception and metaperception of architectural designs communicated by video-computer imaging. Psychological Research-Psychological Forschung, 53, 113-126.

36. Siskos, A., Antoniou, P., Papaioannou, A., \& Laparidis, K. (2005). Effects of multimedia computer-assisted instruction (MCAI) on academic achievement in physical education of Greek primary students. Interactive Educational Multimedia, 10, 61-77.

37. Sweller, J. (1999). Instructional design in technological areas. Camberwell, Australia: ACER Press.

38. Fiorentino, L.H., \& Castelli, D.M. (2005). Creating a virtual gymnasium: Providing an opportunity for perfect practice. Journal of Physical Education, Recreation and Dance, 76(4), 16-18.

39. Hegarty, M., Kriz, S., \& Cate, C. (2003). The roles of mental animations and external animations in understanding mechanical systems. Cognition \& Instruction, 21(4), 325-360. 
40. Chu, H., \& Chen, W. (2000). Multimedia application to motor skill learning. Proceedings of ED-MEDIA 2000, Montreal, USA: July (2), 1257-1258.

41. Cope, B., \& Kalantzis, M.A. (2009). Multiliteracies: New Literacies, New Learning. Pedagogies: An International Journal, 4, 164-195.
42. Crafton, L.K., Brennan, M., \& Silvers, P. (2007). Critical inquiry and multiliteracies in a FirstGrade classroom. Language Arts, 84(6), 510-518.

\section{ANIMATION MIT SIMULTANER NARRATION GEGENÜBER NARRATION IM SPORTUNTERRICHT}

\section{Zusammenfassung:}

Ziel dieser Untersuchung war es, einen Vergleich der Effekte festzustellen, die zwei unterschiedliche Lehrmethoden auf das Verständnis der Schüler im Sportunterricht ausüben: Narration in Gegenüberstellung zu Animation mit simultaner Narration während des Unterrichts zum Thema Kugelstoßen. An dieser Untersuchung nahmen auf freiwilliger Basis 30 Kinder im Grundschulalter (Jungen und Mädchen) teil. Während des Experiments hörten (Narration) sie und schauten (Animation mit Narration) eine Präsentation über zwei Stile der Sportdisziplin Kugelstoßen an. Ein Test über Problemlösungen und ein Test für Wissensretention wurden für die Einschätzung des Verständnisses verwendet. Die Ergebnisse weisen darauf hin, dass die Schüler eine höhere Verständnisebene erzielten, wenn die Stile der Sportdisziplin Kugelstoßen mit Hilfe des Mischmodells (Animation mit Narration) dargestellt wurden. Die Gruppe, der die Inhalte durch Animation mit Narration dargestellt wurden, erzielte bessere Ergebnisse als die Gruppe, der die Inhalte nur durch Narration präsentiert wurden - der Test der Problemlösung $(M=4,91, S D=1,36)$, der Test der Wissensretention $(M$ $=5,98, \mathrm{SD}=1,28) \tau(28)=1,89 \Pi<0,01$. Die Schlussfolgerung weist darauf hin, dass in einem kontinuierlichen Sportunterricht Bilder gemeinsam mit Worten eine effizientere Lehrmethode im Vergleich zur Methode, in der nur Worte verwendet werden, darstellen.

Schlüsselwörter: THEORIE DER DOPPELTEN KODIERUNG / BILDER / WORTE / KUGELSTOßVERANSTALTUNG

Примљен: 07.09.2016.

Прихваћен: 02.11.2016.

(c) 2016 Autor. Objavio Fizička kultura (www.fizickakultura.com). Ovo je članak otvorenog pristupa i distribuira se u skladu sa Creative Commons licencom (http://creativecommons.org/licenses/by/3.0/rs/). 